\title{
Reliability-based calibration of Brazilian structural design codes used in the design of concrete structures
}

\section{Calibração baseada em confiabilidade das normas brasileiras usadas em projetos de estruturas de concreto}
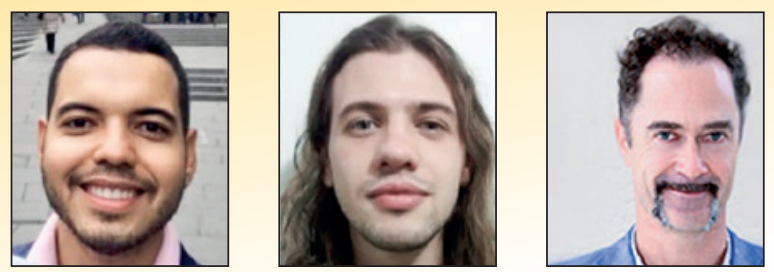

W. C. SANTIAGO wagner.santiago@univasf.edu.br https://orcid.org/0000-0002-7939-5855

H. M. KROETZ b henrique.kroetz@ufpr.br https://orcid.org/0000-0003-3977-1112

A. T. BECK ${ }^{c}$

atbeck@sc.usp.br https://orcid.org/0000-0003-4127-5337

\begin{abstract}
This paper presents a reliability-based calibration of partial safety factors for Brazilian codes used in the design of concrete structures. The work is based on reliability theory, which allows an explicit representation of the uncertainties involved in terms of resistances and loads. Regarding the resistances, this study considers beams with concrete of five classes (C20, C30, C40, C50 and C60), three ratios between base and effective depth (0.25, 0.50 and 0.75), three longitudinal reinforcement ratios $\left(\rho_{\min }, 0.5 \%\right.$ and $\left.\rho_{\max }\right)$ and three transverse reinforcement ratios $\left(\left(\frac{\mathrm{As}}{\mathrm{s}}\right)_{\min }, 5 .\left(\frac{\mathrm{As}}{\mathrm{s}}\right)_{\min }\right.$ and $\left.\left(\frac{A s}{\mathrm{~s}}\right)_{\max }\right)$. In terms of loads, this work considers seven ratios between live loads and permanent loads (qn/gn), and seven ratios between wind loads and permanent loads $\left(w_{n} / g_{n}\right)$. The study also adopts a single value for the target reliability index $\left(\beta_{\text {target }}=3.0\right)$. Results show that the optimized set of partial safety factors leads to more uniform reliability for different design situations and load combinations.
\end{abstract}

Keywords: code calibration, concrete structures, structural safety, reliability, safety, NBR 8681, NBR 6118.

\section{Resumo}

Este artigo apresenta a calibração, baseada em confiabilidade, dos coeficientes parciais de segurança das normas brasileiras utilizadas no dimensionamento de estruturas de concreto. O trabalho está fundamentado na teoria de confiabilidade, que permite uma representação explícita das incertezas envolvidas em termos das resistências e ações. No que tange às resistências, são consideradas vigas projetadas para resistir a esforços de flexão e cisalhamento com concretos de cinco classes (C20, C30, C40, C50 e C60), três razões entre base e altura útil $(0,25,0,50$ e $0,75)$, três taxas geométricas de armaduras longitudinais $\left(\rho_{\min }, 0,5 \%\right.$ e $\left.\rho_{\max }\right)$ e três taxas de armaduras transversais $\left(\left(\frac{A s}{\mathrm{~s}}\right)_{\min }, 5 .\left(\frac{A s}{\mathrm{~s}}\right)_{\min } \mathrm{e}\left(\frac{A s}{\mathrm{~s}}\right)_{\max }\right)$. No tocante às ações, são consideradas sete razões entre os carregamentos acidental e permanente (qn/gn), e sete razões entre os carregamentos do vento e permanente $\left(w_{n} / g_{n}\right)$. O estudo ainda adotou um único valor para o índice de confiabilidade alvo $\left(\beta_{\text {alvo }}=3,0\right)$. Os resultados mostraram que os conjuntos otimizados dos coeficientes parciais de segurança conduzem a uma confiabilidade mais uniforme para diferentes situações de projeto e combinações de carregamentos.

Palavras-chave: calibração de norma, estruturas de concreto, confiabilidade, segurança, NBR 6118, NBR 8681. 


\section{Introduction}

Every structural design has uncertainties associated to construction materials and to the actions it will be subject to during execution and the useful life. Brazilian structural codes incorporate these uncertainties through limit state design, a method that establishes boundaries between desirable and undesirable structural behaviors.

According to this method, the safety of a structure is determined by its ability to support actions without reaching any ultimate limit state or serviceability limit state. The ultimate limit states are associated to loss of equilibrium of the structure or parts of it; while the serviceability limit states are related to the functionality of the structure.

Limit state design involves use of partial safety factors that control the risk against failure of a structure. Therefore, there are factors to reduce the resistance of the structural elements and to increase the actions, creating a margin of safety in relation to the main sources of uncertainties.

A reliability-based calibration process converted the American structural codes to this format. However, there is no clear evidence in the literature that the partial safety factors indicated in European codes derived from a generalized calibration process.

The safety factors indicated in Brazilian codes were not properly calibrated and were adapted from American and European codes. It is imperative that national codes be calibrated based on uncertainties that reflect the Brazilian reality, in terms of materials, actions and calculation models.

\section{Objectives}

This work aims to present a first study about the partial safety coefficients indicated in the main Brazilian codes used in the design of concrete structures: structural actions code [1] and concrete structures design code [2].

The study is based on structural reliability theory, which allows an explicit representation of uncertainties through consideration of resistances and loads as random variables, resulting in a quantitative estimation of safety: the reliability index $(\beta)$.

The work involves a calibration methodology oriented to obtain a set of partial safety factors that minimizes the variations of the reliability indexes of different types of reinforced concrete beams projected according to Brazilian codes, in relation to the chosen target reliability index $\left(\beta_{\text {target }}\right)$.

This study is important because it presents sets of partial safety factors that best reflect the reality of Brazilian concrete structures. It also reveals the need for an extensive calibration that contemplates other types of structural materials and elements.

\section{Context}

The code calibration process is intended to adjust safety factors that lead to designs with a desired level of reliability. In this way, calibration is the process of finding the set $\left\{\gamma_{c}, \gamma_{s}, \gamma_{q}, \gamma_{q}, \gamma_{w}, \psi_{a}\right.$ and $\left.\psi_{w}\right\}$ that minimizes the variations of the reliability indexes of the most diverse structures designed within the scope of a certain code, with respect to the target reliability index.
In the 1970s, the first publications were made with statistical results of loads, materials strength and load combinations for different types of structures [5]. These results allowed a first reliabilitybased calibration of American structural design codes in the 1980s. There is no clear evidence that European codes have gone through a similar calibration process, despite the clear effort of the Joint Committee on Structural Safety (JCSS), composed by professionals from different countries and involved with structural reliability research.

Since the beginning of this century, research has been conducted with respect to American concrete structures [6-10].

As the Brazilian structural design codes have been adapted to the limit state format from the American and European codes, it is evident that Brazilian partial safety factors have not been calibrated for the reality of the country.

A first approach to the calibration of Brazilian codes was made by Souza Jr [11], dealing specifically with steel structures. Subsequently, Nova and Silva [12] produced a preliminary calibration of Brazilian codes used in the design of prestressed concrete bridges.

\section{Methodology}

The present work deals with reliability-based calibration of the partial safety factors indicated in the main Brazilian codes used in the design of concrete structures. The procedure follows the main guidelines in Melchers and Beck [13]. Briefly, the calibration involves two major steps: the collection of statistics related to the reality of materials, loads and desing models in Brazil, and the calibration of partial safety factors. It should also be mentioned that the reliability problem was solved using the StRAnD program - Structural Reliability Analysis and Design - developed by Beck [14] at the Department of Structural Engineering of the School of Engineering of São Carlos.

\section{Brazilian statistics}

In this section we present the random variables related to Brazilian concrete structures. The distributions of the variables not available in the literature were adjusted based on the Chi-Square, Kolmogorov-Smirnov and Anderson-Darling goodness-of-fit tests, after exclusion of outliers.

\subsection{Resistance variables}

The following resistance variables related to concrete beams built in Brazil were adopted: concrete compressive strength $\left(f_{c}\right)$, yield strength of reinforcing bars $\left(f_{y}\right)$, cross section base (b), effective depth (d) and professional factor or resistance model uncertainties $\left(\mathrm{E}_{\mathrm{m}}^{\mathrm{R}}\right)$. A summary of the results concerning these variables is shown in Table 1; it is important to notice that the means are expressed as a function of their respective characteristic or nominal values.

Statistics in Table 1 were obtained from results of axial compression tests at 28 days performed in more than 39 thousand cylindrical specimens of concrete molded in loco all over Brazil, between 2011 and 2016, as reported by Santiago and Beck $[15,16,17]$. As in the work of Nowak et al. [8], the parameters of the probability distribution functions of the variables were ob- 
Table 1

Resistance random variables

\begin{tabular}{|c|c|c|c|c|}
\hline \multicolumn{2}{|c|}{ Random variable } & Distribution & Mean & C.V. \\
\hline \multirow{5}{*}{$f_{c}$} & $\mathrm{C} 20$ & Normal & $1.30 . f_{c k}$ & 0.20 \\
\hline & C30 & Normal & $1.22 . f_{c k}$ & 0.15 \\
\hline & $\mathrm{C} 40$ & Normal & $1.16 . f_{c k}$ & 0.11 \\
\hline & C50 & Normal & $1.11 . f_{c k}$ & 0.10 \\
\hline & C60 & Normal & $1.10 . f_{c k}$ & 0.09 \\
\hline \multicolumn{2}{|c|}{$f_{y}$} & Normal & $1.22 . f_{y k}$ & 0.04 \\
\hline \multicolumn{2}{|c|}{ b } & Normal & $b_{n}$ & $\left(4+0,006 \cdot b_{n}\right) / b_{n}$ \\
\hline \multicolumn{2}{|c|}{ d } & Normal & $d_{n}$ & $10 \mathrm{~mm} / \mathrm{d}_{\mathrm{n}}$ \\
\hline \multirow{2}{*}{$\mathrm{E}_{\mathrm{m}}^{\mathrm{R}}$} & Flexural resistance & Normal & 1.02 & 0.06 \\
\hline & Shear resistance & Normal & 1.075 & 0.10 \\
\hline
\end{tabular}

tained from the adjustment of probability density function (Figure 1). Table 2 presents a quantification of the specimens according to the strength class. It should be mentioned that these results were provided by the following companies, educational institutions and laboratories: AJL Engenharia, Centro de Tecnologia da UFAL, CONSULTARE Laboratório, CSP Projetos e Consultoria, EGELTE Engenharia, ITAIPU BINACIONAL, Laboratório de Ensaios de Materiais da FACENS, Laboratório de Materiais de Construção e Técnicas Construtivas da UNIVASF, MPA Controle Tecnológico, SENAI-DF, SILCO Engenharia, TECNOL Tecno-

\section{Table 2}

Quantification of specimens by concrete class

\begin{tabular}{cc}
\hline Classe & Quantity \\
\hline C20 & 4511 \\
C25 & 1053 \\
C30 & 6685 \\
C35 & 7804 \\
C40 & 3982 \\
C45 & 2527 \\
C50 & 13272 \\
\hline
\end{tabular}

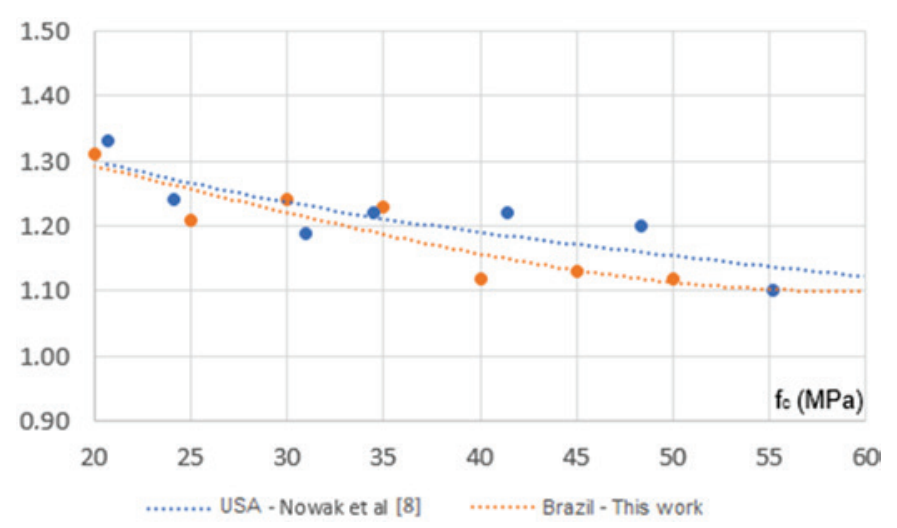

a $\mu$ logia em Concreto, TECNOCON Engenharia e VENTUSCORE Soluções em Concreto.

The variable $f_{y^{\prime}}$, on the other hand, was based on results from tensile tests performed in more than 8.7 thousand samples of CA-50 bars with different diameters and produced in several batches in Brazil throughout 2016. Table 3 presents a quantification of the specimens according to the size. It should be noted that these results were provided directly by ArcelorMittal Brasil, which is the largest producer of steel in Latin America, and one of the main manufacturers of reinforcing bars in Brazil.

The impossibility of carrying out an experimental study associated with the scarcity of publications on the subject resulted in

\section{Table 3}

Quantification of specimens by reinforcing bar size

\begin{tabular}{cc}
\hline$\varnothing(\mathrm{mm})$ & Quantity \\
\hline 8 & 3352 \\
12.5 & 2416 \\
16 & 1441 \\
20 & 571 \\
25 & 961 \\
\hline
\end{tabular}

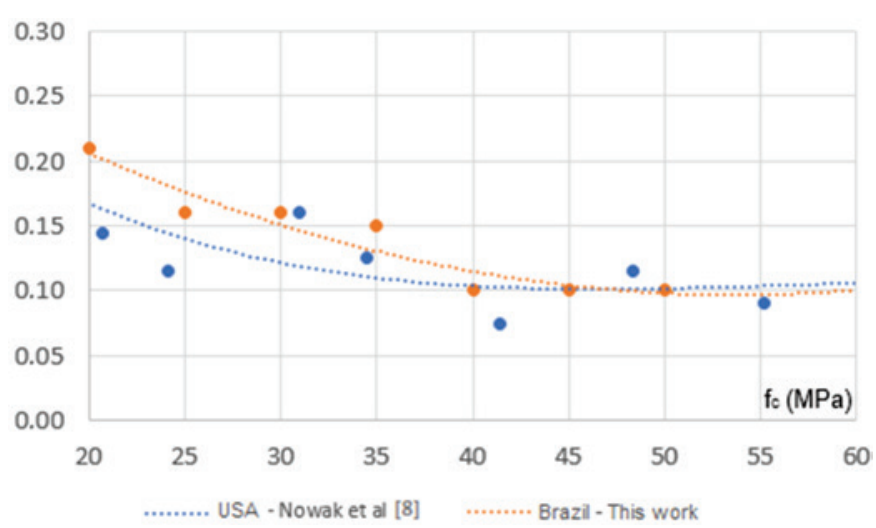

(b) C.V.

\section{Figure 1}

Recommended parameters for the probability distribution functions of the variable $f_{c}$ 


\section{Table 4}

Load random variables

\begin{tabular}{|c|c|c|c|c|}
\hline \multicolumn{2}{|c|}{ Variável aleatória } & Distribuição & Média & C.V. \\
\hline \multicolumn{2}{|c|}{$g$} & Normal & $1.06 . g_{n}$ & 0.12 \\
\hline \multicolumn{2}{|c|}{$\mathrm{q}_{\mathrm{apt}}$} & Gamma & $0.25 . q_{n}$ & 0.55 \\
\hline \multicolumn{2}{|c|}{$\mathrm{q}_{50}$} & Gumbel & $1.00 . q_{n}$ & 0.40 \\
\hline \multicolumn{2}{|c|}{$w_{1}$} & Gumbel & $0.33 . w_{n}$ & 0.47 \\
\hline \multicolumn{2}{|c|}{$W_{50}$} & Gumbel & $0.90 . w_{n}$ & 0.34 \\
\hline \multirow{2}{*}{$\mathrm{E}_{\mathrm{m}}^{\mathrm{S}}$} & Flexural resistance & Log-normal & 1.00 & 0.10 \\
\hline & Shear resistance & Log-normal & 1.00 & 0.10 \\
\hline
\end{tabular}

the adoption of the prescriptions of Brazilian concrete structures construction code [18] and of the JCSS [19] in the definition of variables $b$ and $d$.

The random variable $E_{m}^{R}$, which expresses the difference between the actual strength of a structural element and the behavior predicted by a calculation model, corresponded to the distributions indicated by Nowak et al. [8] and Stucchi and Santos [20]. This was only possible because these distributions were in line with the calculation models used in Brazilian structural offices.

\subsection{Load variables}

The following load variables related to beams built in Brazil were adopted: dead load $(\mathrm{g})$, arbitrary point in time live load $\left(\mathrm{q}_{\mathrm{apt}}\right)$, 50 year extreme live load $\left(q_{50}\right)$, anual extreme wind load $\left(w_{1}\right), 50$ year extreme wind load $\left(w_{50}\right)$ and load model uncertainties $\left(E_{m}^{S}\right)$. A summary of the results concerning these variables is shown in Table 4; it is important to note that the means are expressed as a function of their respective nominal values.

The dead load variable $\mathrm{g}$ was based on results sent by different structural engineers that determined the weight of the same building based on the return given by the construction companies that hired them. The multi-storey residential building represents a generalization of the most commonly constructed buildings in Brazil. The following structural engineers participated in the study: Carlos Baccini, Cesar Pinto, Daniel Miranda, Douglas Couto, Enio Barbosa, Fernando Stucchi, Josafá de Oliveira Filho, Luiz Cabral, Murilo Marques, Paulo Sousa, Rodrigo Nurnberg e Vitor Hugo.

The life load variables $q_{\text {apt }}$ and $q_{50}$ were based on two reference tributary areas and two shape factors from the stochastic model

\section{Table 5}

Weights $w_{i j}$ for different ratios $q_{n} / g_{n}$ or $w_{n} / g_{n}$ (adapted from Ellingwood et al [5])

\begin{tabular}{cc}
\hline $\mathbf{q}_{\mathrm{n}} / \mathrm{g}_{\mathrm{n}}$ or $\mathbf{w}_{\mathrm{n}} / \mathrm{g}_{\mathrm{n}}$ & $\mathbf{w}_{\mathrm{ij}}$ \\
\hline 0 & 0.10 \\
0.5 & 0.45 \\
1.0 & 0.30 \\
1.5 & 0.10 \\
2.0 & 0.05 \\
3.0 & 0 \\
5.0 & 0 \\
\hline
\end{tabular}

proposed in JCSS [19]. In this way, the load was divided in two independent parts - sustained and intermittent - in which the time between changes was represented by an exponential distribution and the number of changes by a Poisson process. From the maximum load obtained by the sum between the sustained and intermittent loads in a reference period, it was possible to adjust distributions for both variables based on the revised load values prescribed by the Brazilian code about loads for structural design [21].

Wind load variables $w_{1}$ and $w_{50}$ assumed the results proposed by Beck and Souza Jr. [4], which were based on wind speed series obtained in Brazilian meteorological stations.

Due to the lack of papers on the uncertainties associated with the definitions of effects in concrete structures design, the random variable $E_{\mathrm{m}}^{\mathrm{S}}$ was based on the information provided by the JCSS [19].

\section{Calibration}

Calibration procedure is presented in this section, as well as the cases considered in the determination of the new Brazilian partial safety factors indicated in the structural safety code [1] and in the concrete structures design code [2].

\subsection{Procedures}

The calibration of the safety factors was formulated as a reliabilitybased design optimization (RBDO) problem, in which the uncertainties involved, represented as random variables (as shown in Tables 1 and 4), were considered explicitly. The calibration problem can be stated as:

find: $\mathrm{\gamma}_{c^{\prime}}, \mathrm{\gamma}_{S}, \mathrm{\gamma}_{\mathrm{g}}, \mathrm{\gamma}_{q}, \mathrm{\gamma}_{w^{\prime}}, \psi_{q}$ e $\psi_{w}$

that minimizes: $\mathrm{D}_{f}=\sum_{i=1}^{m} \sum_{j=1}^{n}\left\{\left[\beta_{\text {target }}-\min _{k}\left(\beta_{i j k}\right)\right]^{2} \cdot w_{i j}\right\}$

where $m$ and $n$ are the load ratios considered, $\beta_{\mathrm{ijk}}$ is the reliability index calculated for the load ratios $\mathrm{ij}, \mathrm{w}_{\mathrm{ij}}$ is the weight of each load ratio in the combination, according to the relative importance of that design case (Table 5), and $\mathrm{k}$ is the critical limit state among the cases considered in Eq. 2.

$\left\{\begin{array}{l}g_{1}(X)=E_{m}^{R} \cdot R\left(f_{c}, f_{y}, \text { b e d }\right)-E_{m}^{S} \cdot S\left(g+q_{50}+w_{1}\right)=0 \\ g_{2}(X)=E_{m}^{R} \cdot R\left(f_{c}, f_{y^{\prime}} \text {, e d }\right)-E_{m}^{S} \cdot S\left(g+q_{a p t}+w_{50}\right)=0\end{array}\right.$

These two equations are valid for the five combinations that derive from the combination equation proposed by the structural safety 
code [1], as presented in Eq. 3.

$S_{D}=\max \left[\begin{array}{l}\mathrm{\gamma}_{g} \cdot \mathrm{g}_{n} \\ \mathrm{\gamma}_{g} \cdot \mathrm{g}_{n}+\mathrm{\gamma}_{q} \cdot q_{n} \\ \mathrm{\gamma}_{g} \cdot \mathrm{g}_{n}+\mathrm{\gamma}_{w} \cdot w_{n} \\ \mathrm{\gamma}_{g} \cdot \mathrm{g}_{n}+\mathrm{\gamma}_{q} \cdot q_{n}+\mathrm{\gamma}_{w} \cdot \psi_{w} w_{n} \\ \mathrm{\gamma}_{g} \cdot \mathrm{g}_{n}+\mathrm{\gamma}_{w} \cdot w_{n}+\mathrm{\gamma}_{q} \cdot \psi_{q} q_{n}\end{array}\right]$

Reliability indexes were evaluated via the First Order Reliability Method (FORM) [22]. FORM is considered adequate in relation to processing speed, given the large number of reliability indexes that were calculated, as well accurate in dealing with low dimensionality limit state equations that do not present large nonlinearities.

The target reliability index was set as $\beta_{\text {target }}=3$, as this corresponds to the mean of reliability indexes obtained before the calibration; this is also a reference number recommended in Melchers and Beck [ 13].

Finally, the optimization problem was solved through the Particle Swarm Optimization algorithm (PSO), which is a meta-heuristic algorithm oriented at identifying the global minimum in non-convex design spaces [23].

\subsection{Structural configurations}

This work considered beams with concrete of five classes (C20, C30, C40, C50 and C60), three ratios between base and effective depth $(0.25,0.50$ and 0.75$)$, three longitudinal reinforcement ratios ( $\rho$ min, $0.5 \%$ and $\rho$ max) and three transverse reinforcement ratios

$\left(\frac{\mathrm{As}}{\mathrm{s}}\right)_{\min }, 5 .\left(\frac{\mathrm{As}}{\mathrm{s}}\right)_{\min }$ and $\left(\frac{A s}{s}\right)_{\max }$.

It should be mentioned that $\rho_{\min }$ is a function of the concrete compressive strength $\left(f_{c k}\right)$ and $p$ max is a function of the maximum height of the neutral line in the cross section $(x / d \leq 0.45$ for concrete with $\leq 50 \mathrm{MPa}$ and $\mathrm{x} / \mathrm{d} \leq 0.35$ for concrete with $50 \mathrm{MPa}<\mathrm{f}_{\mathrm{ck}} \leq 90 \mathrm{MPa}$ ).

It is also worth noting that $\left(\frac{A_{s}}{S}\right)_{\min }$ is a function of the

\section{Table 6}

Partial safety factors with and without calibration for flexural resistance of reinforced concrete beams

\begin{tabular}{ccc}
\hline \multirow{2}{*}{ Factors } & \multirow{2}{*}{ Without calibration } & \multicolumn{2}{c}{ With calibration } \\
\cline { 3 - 3 } & 1.40 & $\beta_{\text {target }}=3.0$ \\
\hline$\gamma_{c}$ & 1.15 & $1.14(1.15)^{*}$ \\
$\gamma_{s}$ & 1.40 & $1.24(1.25)^{*}$ \\
$\gamma_{g}$ & 1.40 & $1.67(1.65)^{*}$ \\
$\gamma_{a}$ & 1.40 & $1.62(1.60)^{*}$ \\
$\gamma_{w}$ & $0.50 / 0.70 / 0.80$ & $0.32(0.30)^{*}$ \\
$\psi_{a}$ & 0.60 & $0.29(0.30)^{*}$ \\
$\psi_{w}$ & $0.70 / 0.98 / 1.12$ & $0.53(0.50)^{*}$ \\
$\gamma_{q} \cdot \psi_{a}$ & 0.84 & $0.47(0.48)^{*}$ \\
$\gamma_{w} \cdot \psi_{w}$ & &
\end{tabular}

*Approximate values in parentheses. concrete compressive strength $\left(f_{c k}\right)$ and of the cross section base (b), while $\left(\frac{A_{s}}{S}\right)_{\max }$ is a function of the ultimate shear strength $\left(\mathrm{V}_{\mathrm{Rd} 2}\right)$.

The limit state functions used in the calibration process proposed in this study, and related to the flexural resistance of reinforced concrete beams, are expressed in Eq 4.

$$
\left\{\begin{array}{l}
\mathrm{g}_{1}(\mathrm{X})=\mathrm{E}_{\mathrm{m}}^{\mathrm{R}} \cdot\left[A_{s} \cdot \mathrm{f}_{\mathrm{y}} \cdot\left(\mathrm{d}-\frac{\left(\frac{\lambda_{c}}{2}\right) \cdot \mathrm{A}_{\mathrm{s}} \cdot \mathrm{f}_{\mathrm{y}}}{\alpha_{c} \cdot \lambda_{c} \cdot \mathrm{b} \cdot \mathrm{f}_{\mathrm{c}}}\right)\right]-\mathrm{E}_{\mathrm{m}}^{\mathrm{S}} \cdot\left[\mathrm{M}_{\mathrm{g}}+\mathrm{M}_{\mathrm{q}_{50}}+\mathrm{M}_{\mathrm{w}_{1}}\right]=0 \\
\mathrm{~g}_{2}(\mathrm{X})=\mathrm{E}_{\mathrm{m}}^{\mathrm{R}} \cdot\left[A_{s} \cdot \mathrm{f}_{\mathrm{y} \cdot} \cdot\left(\mathrm{d}-\frac{\left(\frac{\lambda_{c}}{2}\right) \cdot \mathrm{A}_{\mathrm{s}} \cdot \mathrm{f}_{\mathrm{y}}}{\alpha_{c} \cdot \lambda_{c} \cdot \mathrm{b} \cdot \mathrm{f}_{\mathrm{c}}}\right)\right]-\mathrm{E}_{\mathrm{m}}^{\mathrm{S}} \cdot\left[\mathrm{M}_{\mathrm{g}}+\mathrm{M}_{w_{50}}+\mathrm{M}_{\mathrm{q}_{a p t}}\right]=0
\end{array}\right.
$$

where $A_{s}$ is the cross-section area of reinforcing bars, determined from the longitudinal reinforcement ratios, $\alpha_{c}$ is the factor related to the Rüsch effect (Eq. 5), and $\lambda_{c}$ is the ratio between the depths of the rectangular and the parabolic-rectangular concrete stress blocks (Eq. 6).

$\alpha_{c}=\left\{\begin{array}{lc}0,85 & \left(\text { for concrete with } \mathrm{f}_{\mathrm{ck}} \leq 50 \mathrm{MPa}\right) \\ 0,85 .\left[1,0-\frac{\left(\mathrm{f}_{\mathrm{ck}}-50\right)}{200}\right] & \left(\text { for concrete with } 50 \mathrm{MPa}<\mathrm{f}_{\mathrm{ck}} \leq 90 \mathrm{MPa}\right)\end{array}\right.$

$\lambda_{c}=\left\{\begin{array}{l}0,80 \\ 0,80-\left[\frac{\left(f_{\mathrm{ck}}-50\right)}{400}\right]\end{array}\right.$

(for concrete with $\mathrm{f}_{\text {ck }} \leq 50 \mathrm{MPa}$ )

(for concrete with $50 \mathrm{MPa}<\mathrm{f}_{\mathrm{ck}} \leq 90 \mathrm{MPa}$ )

The limit state functions used in the calibration process proposed in this work and related to the shear resistance of reinforced concrete beams are expressed in Eq 7.

$\left\{\begin{array}{l}\mathrm{g}_{1}(\mathrm{X})=\mathrm{E}_{\mathrm{m}}^{\mathrm{R}} \cdot\left[\left(\left(\frac{\mathrm{As}}{\mathrm{s}}\right) \cdot 0,9 \cdot \mathrm{d} \cdot \mathrm{f}_{\mathrm{y}}\right)+\left(0,6 \cdot 0,7 \cdot 0,3 \cdot \mathrm{b} \cdot \mathrm{d} \cdot \sqrt[3]{\mathrm{f}_{\mathrm{c}}^{2}}\right)\right]-\mathrm{E}_{\mathrm{m}}^{\mathrm{S}} \cdot\left[\mathrm{V}_{\mathrm{g}}+\mathrm{V}_{\mathrm{q}_{50}}+\mathrm{V}_{\mathrm{w}_{1}}\right]=0 \\ \mathrm{~g}_{2}(\mathrm{X})=\mathrm{E}_{\mathrm{m}}^{\mathrm{R}} \cdot\left[\left(\left(\frac{\mathrm{As}}{\mathrm{s}}\right) \cdot 0,9 \cdot \mathrm{d} \cdot \mathrm{f}_{\mathrm{y}}\right)+\left(0,6 \cdot 0,7 \cdot 0,3 \cdot \text { b.d. } \cdot \sqrt[3]{\mathrm{f}_{\mathrm{c}}^{2}}\right)\right]-\mathrm{E}_{\mathrm{m}}^{\mathrm{S}} \cdot\left[\mathrm{V}_{\mathrm{g}}+\mathrm{V}_{\mathrm{w}_{50}}+\mathrm{V}_{\mathrm{q}_{a p t}}\right]=0\end{array}\right.$

In agreement with the prescriptions of the Brazilian concrete structures design code [2], this study considered the classical RitterMorsch truss with 45 degrees angle. The resistance function of the problem corresponded to the sum of the shear force absorbed by the stirrups and of the shear force absorbed by the complementary mechanisms.

For both problems (beam bending and shear), the conventional design procedure is inverted: instead of finding the required strength for specified loading, beam cross-section and reinforcement ratio are specified, and design strength $\left(R_{D}\right)$ is evaluated, using $\gamma_{c}$ and $\gamma_{s}$ [2]. Based on this strength, and on pre-defined ratios between dead and variable loads, the nominal design code alowable dead load $\left(g_{n}\right)$ is evaluated:

$g_{n}=\left\{\begin{array}{l}\frac{\mathrm{R}_{\mathrm{D}}}{\mathrm{\gamma}_{\mathrm{g}}+\mathrm{\gamma}_{\mathrm{q}} \cdot\left(\mathrm{q}_{\mathrm{n}} / \mathrm{g}_{n}\right)+\mathrm{\gamma}_{\mathrm{w}^{*}} \cdot \Psi_{\mathrm{w}^{*}}\left(\mathrm{w}_{\mathrm{n}} / \mathrm{g}_{n}\right)} \\ \frac{\mathrm{R}_{\mathrm{D}}}{\mathrm{\gamma}_{\mathrm{g}}+\mathrm{\gamma}_{\mathrm{w}} \cdot\left(\mathrm{w}_{\mathrm{n}} / \mathrm{g}_{n}\right)+\mathrm{\gamma}_{\mathrm{q}} \cdot \Psi_{\mathrm{q}} \cdot\left(\mathrm{q}_{\mathrm{n}} / \mathrm{g}_{n}\right)}\end{array}\right.$

\section{Results}

Results obtained from the reliability-based calibration of the partial 


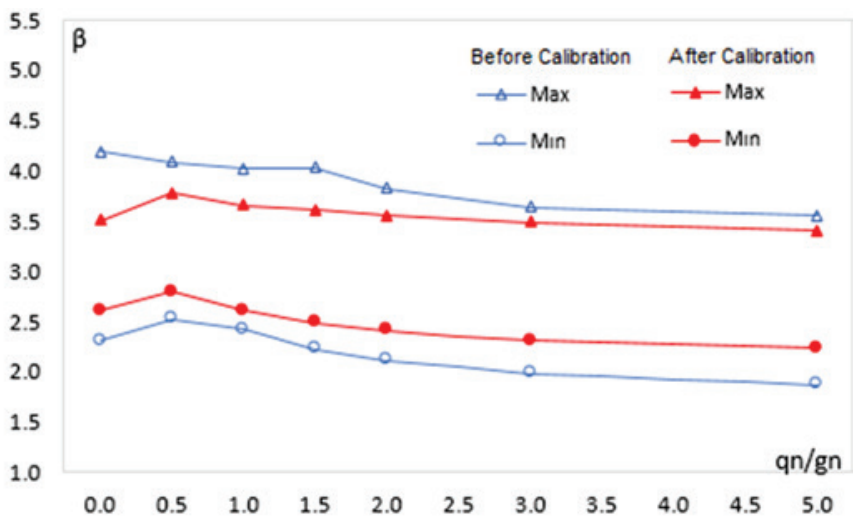

a Bounds for ratios between live loads and permanent loads

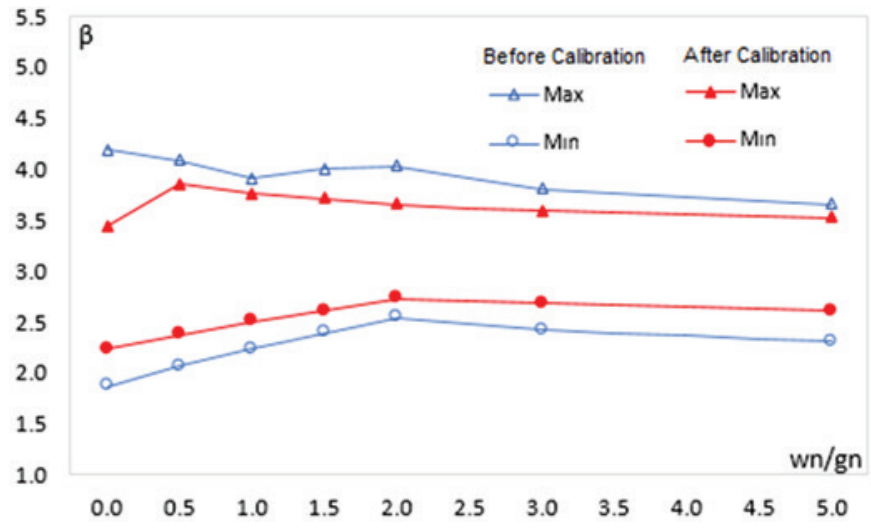

b Bounds for ratios between wind loads and permanent loads

\section{Figure 2}

Reliability index bounds for flexural resistance of reinforced concrete beams and $\beta_{\text {target }=3.0}$

safety factors indicated in the main Brazilian codes that guide the design of concrete structures are presented in this section.

\subsection{The flexural resistance of reinforced concrete beams}

Table 6 presents the set of partial safety factors currently indicated in the actions code [1] and in the concrete structures design code [2], as well as the same set after calibration, related to the flexural resistance of reinforced concrete beams.

It is possible to notice that the reliability-based calibration resulted in a decrease in the values of factors $\gamma_{c}, \gamma_{s}, \gamma_{g}, \Psi_{q}$ and $\Psi_{w}$, which was compensated by the increase in the values of $\gamma_{q}$ and $\gamma_{w}$. Similar to the results observed by Beck and Souza Jr. [4], partial factors resulting from the calibration process increased the primary loads and reduced the secondary loads.

Figure 2 shows the variations of reliability indexes for different loads considering the safety factors before and after calibration. This figure shows

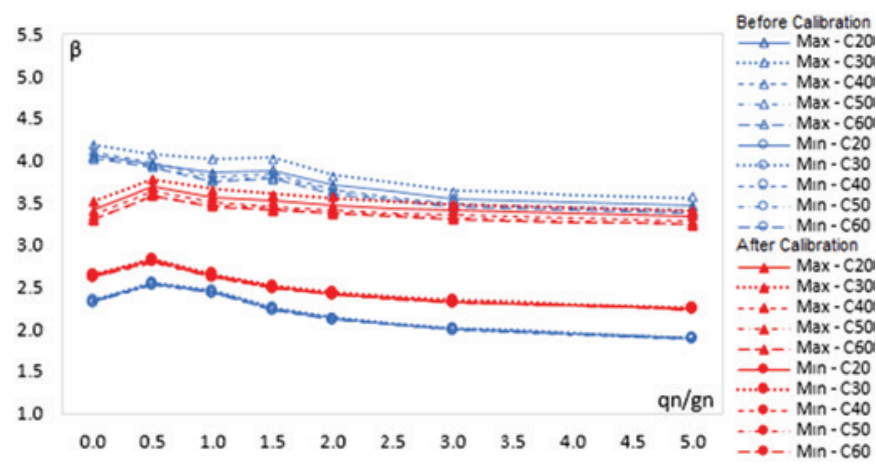

a Bounds for ratios between live loads and permanent loads that the calibrated factors lead to greater uniformity in reliability for different designs and load combinations, given the reduction in dispersion of results and the increase in the average reliability index from 2.95 to 3.0. In order to allow an evaluation of the influence of concrete strength in the calibration, Figure 3 presents the variation of reliability indexes for the concrete classes considered in this study. It shows that for both sets, there is a greater dispersion in the results at the upper limit. The beams with higher longitudinal reinforcement ratios present greater reliability, yet these beams also present greater dispersion in the results. The behavior illustrated in Figure 3 results from increase in the height of the neutral line, which is accompanied by an increase in the height of the concrete stress block, raising the relative importance of variable $f_{c}$, which is directly affected by the differences in its parameters in each concrete class.

The calibrated factors are interesting because they lead to safer concrete beams, but the analysis cannot be limited to technical aspects; it should contemplate at least a brief appreciation of the economic impacts of the new factors.

\section{Figure 3}

Reliability index bounds for flexural resistance of reinforced concrete beams, all concrete classes and $\beta_{\text {target }=3.0}$ 


\section{Table 7}

Partial safety factors with and without calibration for shear resistance of reinforced concrete beams

\begin{tabular}{ccc}
\hline \multirow{2}{*}{ Factors } & \multirow{2}{*}{ Without calibration } & With calibration \\
\cline { 3 - 3 } & & $\beta_{\text {target }}=3.0$ \\
\hline$\gamma_{c}$ & 1.40 & $1.37(1.35)^{*}$ \\
$\gamma_{s}$ & 1.15 & $1.16(1.15)^{*}$ \\
$\gamma_{g}$ & 1.40 & $1.25(1.25)^{*}$ \\
$\gamma_{\mathrm{a}}$ & 1.40 & $1.68(1.70)^{*}$ \\
$\gamma_{\mathrm{w}}$ & 1.40 & $1.63(1.65)^{*}$ \\
$\psi_{\mathrm{a}}$ & $0.50 / 0.70 / 0.80$ & $0.34(0.35)^{*}$ \\
$\psi_{\mathrm{w}}$ & 0.60 & $0.31(0.30)^{*}$ \\
$\gamma_{\mathrm{q}} \cdot \psi_{\mathrm{a}}$ & $0.70 / 0.98 / 1.12$ & $0.57(0.59)^{*}$ \\
$\gamma_{\mathrm{w}} \cdot \psi_{\mathrm{w}}$ & 0.84 & $0.50(0.49)^{*}$ \\
\hline
\end{tabular}

${ }^{*}$ Approximate values in parentheses.

For $\Psi_{\mathrm{q}}=0.5$ the new factors increase the average load by $2.0 \%$, for $\psi_{\mathrm{q}}=0.7$ the new factors do not increase the average load, and for $\psi_{\mathrm{q}}=0.8$ the new factors decrease the average load by $4.0 \%$.

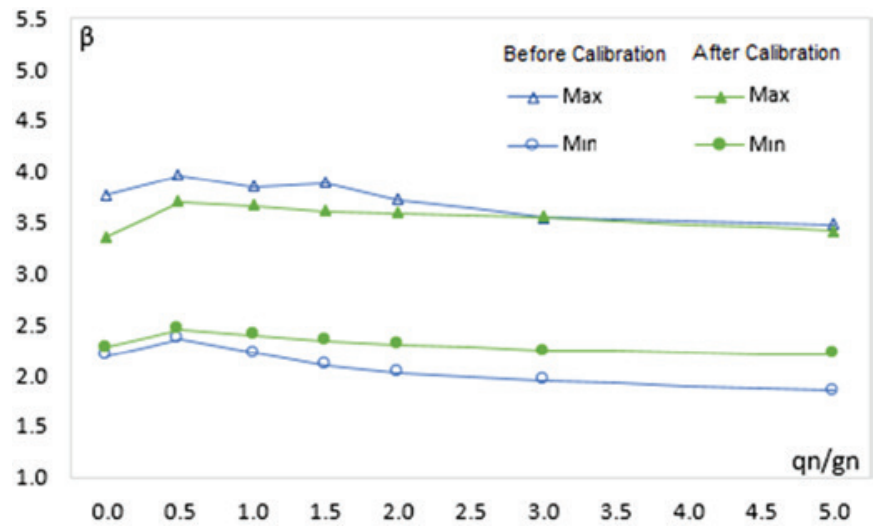

a Bounds for ratios between live loads and permanent loads

\subsection{The shear resistance of reinforced concrete beams}

Table 7 presents the set of partial safety factors currently indicated in the actions code [1] and in the concrete structures design code [2], as well as the same set after the calibration, related to the shear resistance of reinforced concrete beams.

Again, it is possible to observe that the calibrated factors increase the primary loads and reduce the secondary loads. The difference in the factors calibrated for flexural and shear resistance results from the fact that the same target reliability index was adopted for both problems, whereas each one presents an average reliability index of its own.

Figure 4 ilustrates the variations of reliability indexes for different loads, considering the safety factors before and after calibration, while figure 5 presents the variations of reliability indexes for the concrete classes considered in this work. Both figures show that calibrated factors lead to greater uniformity in reliability, for different design cases and load combinations, given the reduction in dispersion of results and the increase in the average reliability index from 2.89 to 3.0 .

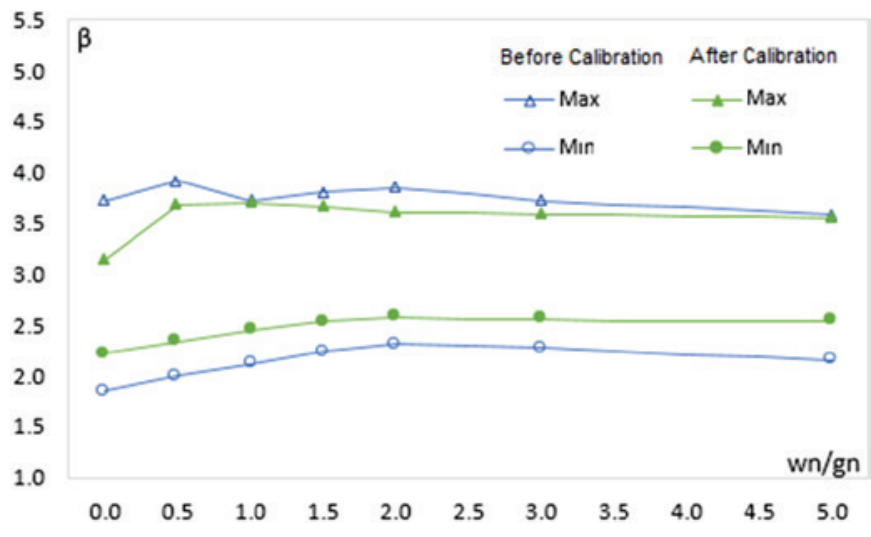

b Bounds for ratios between wind loads and permanent loads

\section{Figure 4}

Reliability index bounds for shear resistance of reinforced concrete beams and $\beta_{\text {target }=3.0}$

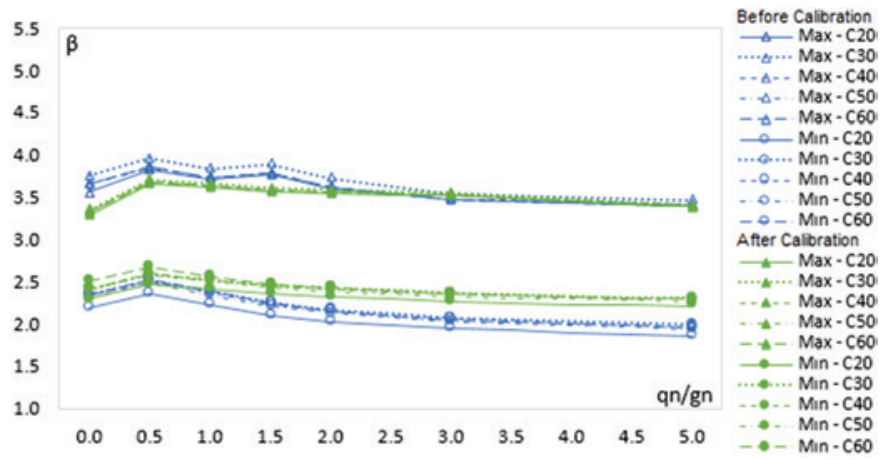

a Bounds for ratios between live loads and permanent loads

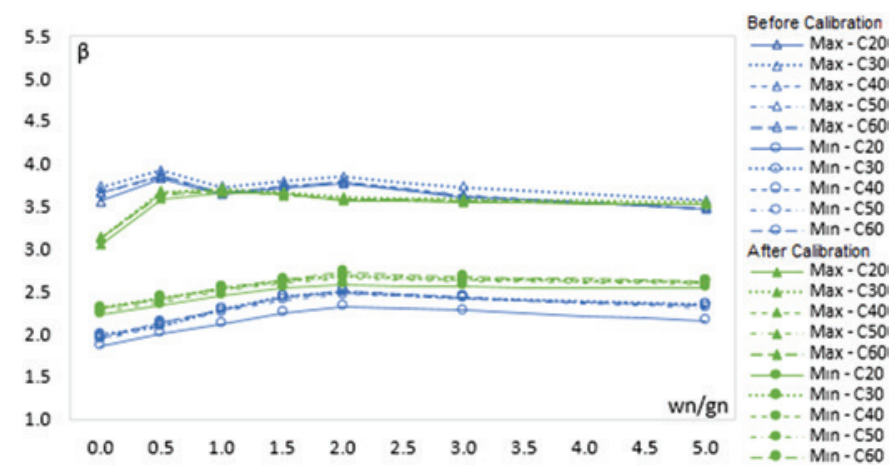

b Bounds for ratios between wind loads and permanent loads

\section{Figure 5}

Reliability index bounds for shear resistance of reinforced concrete beams, all concrete classes and $\beta_{\text {target }=3.0}$ 
In the calibration for shear and for $\psi_{\mathrm{q}}=0.5$ the new factors increase the average load by $3.0 \%$, for $\Psi_{\mathrm{q}}=0.7$ the new factors increase the average load by $0.5 \%$, and for $\Psi_{\mathrm{q}}=0.8$ the new factors decrease the average load by $1.0 \%$.

\subsection{Additional considerations}

Although the impacts of the new partial safety factors vary from project to project, the sets calibrated in this study are interesting from a technical point of view. The presented results reinforce the importance of a calibration that contemplates other types of structural elements and materials, and a detailed study on the economics impacts of the new factors.

\section{Conclusions}

This paper presented a study on reliability-based calibration of partial safety factors indicated in the main Brazilian codes used in the design of concrete structures. The study considered beams with concrete of five classes (C20, C30, C40, C50 and C60), three ratios between base and effective depth $(0.25,0.50$ and 0.75$)$, three longitudinal reinforcement ratios $\left(\rho_{\min }, 0.5 \%\right.$ and $\left.\rho_{\max }\right)$ and three transverse reinforcement ratios $\left(\frac{\mathrm{As}}{\mathrm{s}}\right)_{\min }, 5 .\left(\frac{\mathrm{As}}{\mathrm{s}}\right)_{\min }$ and $\left(\frac{A s}{s}\right)_{\max }$. The work also considered a single value for the target reliability index $\left(\beta_{\text {target }}=3.0\right)$, seven ratios between live loads and permanent loads $\left(\mathrm{q}_{\mathrm{n}} / \mathrm{g}_{\mathrm{n}}\right)$, and seven ratios between wind loads and permanent loads $\left(w_{n} / g_{n}\right)$. The study showed that calibrated factors result in greater uniformity in reliability for different design cases and load combinations, which is mainly achieved by increase in principal loads, and reduction in the secondary loads.

\section{Acknowledgments}

The authors are grateful to CNPq and CAPES for the founding, as well as the professionals who provided the data used to characterize Brazilian statistics for concrete and steel strength, as well as dead loads.

\section{References}

[1] ASSOCIAÇÃO BRASILEIRA DE NORMAS TÉCNICAS. Ação e segurança nas estruturas - procedimento. - NBR 8681, Rio de Janeiro, 2003.

[2] ASSOCIAÇÃO BRASILEIRA DE NORMAS TÉCNICAS. Projeto e execução de estruturas de concreto armado e protendido. - NBR 6118, Rio de Janeiro, 2014.

[3] SANTIAGO, W.C.; KROETZ, H.M.; BECK, A.T. Uma primeira tentativa de calibração baseada em confiabilidade das normas brasileiras usadas em projetos de estruturas de concreto, Anais do $60^{\circ}$ Congresso Brasileiro do Concreto, 2018(to appear).

[4] BECK, A.T.; SOUZA JR, A.C. A first attempt towards reliability-based calibration of Brazilian structural design codes. J, of the Braz. Soc of Mech. Sci \& Eng. V.32, p.119-127, 2010.

[5] ELLINGWOOD, B.; GALAMBOS, T.V.; McGREGOR, J.G.; CORNELL, Development of a Probability Based Load Criterion for American National Standard A58. Special Report 577, U.S. Department of Commerce, National Bureau of Standards, 1980.
[6] NOWAK, A.S.; SZERSZEN, M.M. Calibration of Design Code for Buildings (ACI 318): Part 1-Statistical Models for Resistance, ACI Structural Journal, V. 100, N. 3, p.377-382, 2003.

[7] NOWAK, A.S.; SZERSZEN, M.M. Calibration of Design Code for Buildings (ACl 318): Part 2-Reliability analysis and resistance factors, $\mathrm{ACl}$ Structural Journal, V. 100, N. 3, p.383-391, 2003.

[8] NOWAK, A.S.; RAKOCZY, A.M.; SZELIGA, E., Revised Statistical Resistance Models for R/C Structural Components, ACI SP honoring Andy Scanlon, 2011.

[9] NOWAK, A.S., COLLINS K.R., Reliability of Structures, McGraw-Hill International Editions, Civil Engineering Series, $2^{\text {nd }}$ Edition, 2012.

[10] NOWAK, A. S.; RAKOCZY, A. M. Reliability-Based Calibration of Design Code for Concrete Structures (ACI 318), Anais do $54^{\circ}$ Congresso Brasileiro do Concreto, 2012.

[11] SOUZA JUNIOR, A.C. de. Aplicação de confiabilidade na calibração de coeficientes parciais de segurança de normas brasileiras de projeto estrutural. Dissertação de mestrado. Escola de Engenharia de São Carlos - Universidade de São Paulo. São Carlos, 2009.

[12] NOVA, S.J.S.; SILVA, M.C.A.T.Cálculo dos coeficientes parciais de segurança para pontes de concreto protendido sob solicitações normais com base na teoria de confiabilidade estrutural, Anais do $59^{\circ}$ Congresso Brasileiro do Concreto, 2017.

[13] Melchers, R.E.; BECK, A.T. Structural Reliability Analysis and Prediction, $3^{\text {nd }}$ edition, John Wiley and Sons, 2018.

[14] BECK, A.T. StRAnD: manual do usuário. Escola de Engenharia de São Carlos - Universidade de São Paulo. São Carlos, 2007.

[15] SANTIAGO, W.C.; BECK, A.T. A new study of Brazilian concrete strength conformance. Revista IBRACON de Estruturas e Materiais, V.10, N. 4, p.906-923, 2017.

[16] SANTIAGO, W.C.; BECK, A.T. Um estudo da conformidade da resistência do concreto convencional produzido no Brasil, Anais do $59^{\circ}$ Congresso Brasileiro do Concreto, 2017.

[17] SANTIAGO, W.C.; BECK, A.T. Um estudo da conformidade do concreto de resistência moderada produzido no Brasil, Anais do $60^{\circ}$ Congresso Brasileiro do Concreto, 2018 (to appear).

[18] ASSOCIAÇÃO BRASILEIRA DE NORMAS TÉCNICAS. Execução de estrturas de concreto - procedimento. - NBR 14931, Rio de Janeiro, 2004.

[19] JCSS - Joint Committee on Structural Safety, 2001: "Probabilistic Model Code", disponível online http://www.jcss.byg. dtu.dk/Publications/Probabilistic_Model_Code.aspx, acessado em 22/01/2018.

[20] STUCCHI, F.R.; SANTOS, S.H.C. Reliability based comparison between ACI 318-05 and NBR 6118e. Revista IBRACON de Estruturas e Materiais, V.3, N. 2, p.230-239, 2007.

[21] ASSOCIAÇÃO BRASILEIRA DE NORMAS TÉCNICAS. Cargas para o cálculo de estruturas de edificações. - NBR 6120, Rio de Janeiro, 1980.

[22] HASOFER, A.M., LIND, N.C. (1974). Exact and invariant second-moment code format. Journal of the Engineering Mechanics division, 100(1), 111-121.

[23] KENNEDY, J.; EBERHART, R. (1995). "Particle Swarm Optimization". Proceedings of IEEE International Conference on Neural Networks. IV. pp. 1942-1948. 